\title{
MEDIATION OF ATTACHMENT OF BURKHOLDERIA PSEUDOMALLEI TO HUMAN PHARYNGEAL EPITHELIAL CELLS BY THE ASIALOGANGLIOSIDE GM1-GM2 RECEPTOR COMPLEX
}

\author{
AHMAD HAMID GORI, KAMRUDDIN AHMED, GLENDA MARTINEZ, HIRONORI MASAKI, KIWAO WATANABE, AND \\ TSUYOSHI NAGATAKE \\ Department of Internal Medicine, Institute of Tropical Medicine, Nagasaki University, Nagasaki, Japan
}

\begin{abstract}
Melioidosis is the term given to any infection caused by Burkholderia pseudomallei. This bacteria is one of the important causative agents of life-threatening pulmonary infections in the tropical and subtropical areas. The initiation of respiratory infections is attachment of this bacteria to pharyngeal cells. The precise mechanism of attachment of $B$. pseudomallei is not known. In this study, we found that asialoganglioside GM1 at concentrations of $25,12.5$, and $5 \mu \mathrm{g} / \mathrm{ml}$ significantly decreased the attachment of $B$. pseudomalle $i$ strain Sp-186 in a dose-dependent manner. On the other hand, asialoganglioside GM2 decreased the attachment of B. pseudomallei, but only at a concentration of $25 \mu \mathrm{g} / \mathrm{ml}$. At a concentration of $1 \mathrm{mg} / \mathrm{ml}$, glucose, $N$-acetyl-galactosamine, and galactose caused a significant decrease in attachment. However, at concentrations of $250 \mu \mathrm{g} / \mathrm{ml}$, no decrease in attachment was observed in $B$. pseudomallei treated with these carbohydrates. Mannose and fucose at concentrations of $1 \mathrm{mg} / \mathrm{ml}$ had no effects on the inhibition of attachment of $B$. pseudomallei. Four other isolates of $B$. pseudomallei showed a significant decrease in attachment after treatment with asialoganglioside GM1. We conclude that asialogangliosides GM1 and GM2 are part of the receptor complex for B. pseudomallei on human pharyngeal epithelial cells.
\end{abstract}

Burkholderia pseudomallei can cause a variety of serious and life-threatening infections, collectively known as melioidosis. ${ }^{1,2}$ High relapse, treatment failure, slow response to antibiotic treatment, and drug resistance have made this situation more difficult. ${ }^{3-7}$ Septicemia and pulmonary infections are two main form of infection caused by B. pseudomallei. Kanaphun and others have shown that there is a relationship between pulmonary infection and pharyngeal colonization by this bacteria. ${ }^{8}$ The initial step in the pathogenesis of respiratory infection is the attachment of bacteria to pharyngeal epithelial cells. The bacteria then enter the lower respiratory tract by microaspiration ${ }^{9}$ and establish an infection by overcoming a series of body defense mechanisms. In a recent report, we have shown that $B$. pseudomallei has the capacity to attach to pharyngeal epithelial cells, and have developed a method for the in vitro study of the attachment of this bacteria to these cells. ${ }^{10}$ Bacteria express adhesin, which mediates attachment to a specific receptor present on the host cell. It has been suggested that the receptor of $B$. pseudomalle $i$ on the pharyngeal epithelial cells is a polysaccharide. ${ }^{10}$ Unraveling the mechanism of attachment will help in understanding the pathogenesis of this infection and aid in the development of prevention or treatment strategies based on the anti-attachment mechanism. Therefore, the present study was undertaken to identify the receptor for $B$. pseudomallei on human pharyngeal epithelial cells.

\section{MATERIALS AND METHODS}

Bacteria. Five isolates of $B$. pseudomallei were used in this study. Three strains (Sp-186, Sp-335 and Sp-140) were isolated from sputum of patients with respiratory tract infections and two strains were isolated from blood (H-99) and urine (U-232) of patients with septicemia and urinary tract infections. All isolates were stocked in brain heart infusion broth (BBL, Microbiology System, Becton Dickinson and Co., Cockeysville, MD) containing 5\% defibrinated horse blood and kept at $-40^{\circ} \mathrm{C}$ until use. Burkholderia pseudom- allei was cultured on brain heart infusion agar (BBL, Microbiology System, Becton Dickinson and Co.) and grown overnight at $37^{\circ} \mathrm{C}$.

Pharyngeal epithelial cells. Pharyngeal epithelial cells were collected from a healthy adult male. The oropharynx was scraped with a cotton swab and cells were collected in tubes containing $0.066 \mathrm{mM}$ phosphate buffer, $\mathrm{pH}$ 7.2. The cells were washed three times (10 min/wash) by centrifugation at $80 \times g$ at room temperature, and adjusted to a concentration of $2.5 \times 10^{4}$ cells $/ \mathrm{ml}$.

Treatment of bacteria with carbohydrates. Burkholderia pseudomalle $i$ at a concentration of $1 \times 10^{8}$ colonyforming units (cfu)/ml was treated with different concentrations of glucose, mannose, fucose, $\mathrm{N}$-acetyl-galactosamine, galactose (Wako Pure Chemical Industries, Ltd., Tokyo, Japan), asialoganglioside M1 (AGM1), and asialoganglioside M2 (AGM2) (Sigma Chemical Co., St. Louis, MO) suspended in phosphate buffer in a shaking water bath for 30 $\min$ at $37^{\circ} \mathrm{C}$.

Attachment assay. The attachment assay was done as previously described. ${ }^{10}$ Bacteria at a concentration of $1 \times$ $10^{8} \mathrm{cfu} / \mathrm{ml}$ suspended in phosphate-buffered saline (PBS), $\mathrm{pH} 7.2$, and pharyngeal epithelial cells at a concentration of $2.5 \times 10^{4}$ cells $/ \mathrm{ml}$, were mixed at a ratio of $1: 1$ (i.e., 4,000 bacteria per pharyngeal epithelial cell). The mixture was incubated in a shaking water bath at $37^{\circ} \mathrm{C}$ for $30 \mathrm{~min}$. Unattached bacteria were removed by three washings $(10 \mathrm{~min} /$ wash) with PBS by centrifugation at $80 \times g$ at room temperature. Cells were collected on a glass slide with a Cytospin apparatus (Shandon, Astmoor, United Kingdom). Smears were Gram-stained and viewed under an oil-immersion lens of a light microscope to count the number of bacteria attached to 50 consecutive cells. The mean of duplicate experiments was determined in each case.

Statistical analysis. Statistical analysis was done using the $t$-test. Data were considered significant if a $P$ value was $<0.05$. 
TABLE 1

Attachment of Burkholderia pseudomallei to pharyngeal epithelial cells after treatment with different carbohydrates

\begin{tabular}{|c|c|c|c|c|}
\hline Carbohydrate* & No. of experiments & Amount & Attachment $\dagger$ & $P 末$ \\
\hline \multirow[t]{4}{*}{ AGM1 } & 4 & $25 \mu \mathrm{g} / \mathrm{ml}$ & $38.3 \pm 13.9$ & $<0.005$ \\
\hline & 4 & $12.5 \mu \mathrm{g} / \mathrm{ml}$ & $65.0 \pm 8.9$ & $<0.005$ \\
\hline & 5 & $5 \mu \mathrm{g} / \mathrm{ml}$ & $68.6 \pm 15.5$ & $<0.05$ \\
\hline & 3 & $2.5 \mu \mathrm{g} / \mathrm{ml}$ & $92.3 \pm 8.5$ & NS \\
\hline \multirow[t]{3}{*}{ AGM2 } & 4 & $25 \mu \mathrm{g} / \mathrm{ml}$ & $53.7 \pm 24.4$ & $<0.05$ \\
\hline & 4 & $12.5 \mu \mathrm{g} / \mathrm{ml}$ & $73.2 \pm 21.0$ & NS \\
\hline & 3 & $5 \mu \mathrm{g} / \mathrm{ml}$ & $95.9 \pm 12.4$ & NS \\
\hline \multirow{2}{*}{ Glucose } & 4 & $1 \mathrm{mg} / \mathrm{ml}$ & $50.1 \pm 16.4$ & $<0.01$ \\
\hline & 3 & $250 \mu \mathrm{g} / \mathrm{ml}$ & $85.5 \pm 8.9$ & NS \\
\hline \multirow[t]{2}{*}{ Galactose } & 3 & $1 \mathrm{mg} / \mathrm{ml}$ & $53.2 \pm 5.3$ & $<0.005$ \\
\hline & 3 & $250 \mu \mathrm{g} / \mathrm{ml}$ & $77.9 \pm 13.6$ & NS \\
\hline \multirow[t]{2}{*}{$\mathrm{N}$-acetyl-galactosamine } & 3 & $1 \mathrm{mg} / \mathrm{ml}$ & $41.8 \pm 13.7$ & $<0.05$ \\
\hline & 3 & $250 \mu \mathrm{g} / \mathrm{ml}$ & $86.9 \pm 8.9$ & NS \\
\hline Mannose & 3 & $1 \mathrm{mg} / \mathrm{ml}$ & $82.0 \pm 22.5$ & NS \\
\hline Fucose & 4 & $1 \mathrm{mg} / \mathrm{ml}$ & $111.3 \pm 61.8$ & NS \\
\hline
\end{tabular}

$\dagger$ Attachment (mean \pm SD) of bacteria after treatment with different carbohydrates is expressed as the percentage of bacterial attachment compared with the control.

$\ddagger \mathrm{NS}=$ not significant.

RESULTS

The mean \pm SD attachment value of strain Sp-186 was $4.9 \pm 2.6 \mathrm{bacteria} / \mathrm{cell}$. After treatment with AGM1 at concentrations of $25,12.5,5$, and $2.5 \mu \mathrm{g} / \mathrm{ml}$, attachment was 38 $\pm 13.9 \%(P<0.005), 65 \pm 8.9 \%(P<0.005), 68.6 \pm$ $15.5 \%(P<0.05)$, and $92.3 \pm 8.5 \%$ ( $P$ not significant $)$ of the control, respectively. A dose-dependent effect was found in the inhibition of attachment by AGM1. Conversely, after treatment with AGM2 at concentrations of 25, 12.5, and 5 $\mu \mathrm{g} / \mathrm{ml}$, attachment was $53.7 \pm 24.4 \%(P<0.05), 73.2 \pm$ $21.0 \%(P=$ not significant $)$, and $95.9 \pm 12.4 \%(P=$ not significant) of the control, respectively.

At glucose, $N$-acetyl-galactosamine and galactose concentrations of $1 \mathrm{mg} / \mathrm{ml}$, attachment of B. pseudomallei to pharyngeal epithelial cells was $50.1 \pm 16.4 \%(P<0.01), 41.8$ $\pm 13.7 \%(P<0.05)$, and $53.2 \pm 5.3 \%(P<0.005)$ of the control, respectively. However at a concentration of $250 \mu \mathrm{g} /$ $\mathrm{ml}$, no significant decrease in attachment was observed in B. pseudomallei treated with these carbohydrates. Mannose and fucose had no effects on the inhibition of attachment of B. pseudomallei at concentrations of $1 \mathrm{mg} / \mathrm{ml}$. These data are summarized in Table 1.

After treatment with $12.5 \mu \mathrm{g} / \mathrm{ml}$ of AGM1, there was a significant $(P<0.0005)$ decrease in the attachment of four different isolates (Sp-140, Sp-335, U-232, and H-99) of $B$. pseudomallei (Table 2) to pharyngeal epithelial cells compared with the control. The mean \pm SD attachment of these isolates was $5.4 \pm 1.6 \mathrm{bacteria} / \mathrm{cell}$.

TABLE 2

Effects of $12.5 \mu \mathrm{g} / \mathrm{ml}$ of asialoganglioside GM1 on the attachment of different isolates of Burkholderia pseudomallei on pharyngeal epithelial cells

\begin{tabular}{ll}
\hline Strain no. & \multicolumn{1}{c}{ Attachment* } \\
\hline Sp-140 & $33.0 \pm 0.4$ \\
Sp-335 & $56.5 \pm 12.0$ \\
U-232 & $55.4 \pm 0.5$ \\
H-99 & $49.7 \pm 2.6$ \\
\hline
\end{tabular}

* Percentage of control $(P<0.0005)$.
DISCUSSION

For several respiratory pathogens, the receptor for attachment to cells is located in sequences of gangliosides. Pseudomonas aeruginosa and B. cepacia, which are closely related to B. pseudomallei, has been shown to bind to AGM1 and AGM2. ${ }^{11}$ It has been shown by thin-layer chromatography (TLC) that $B$. pseudomallei also binds to AGM1 and AGM2. ${ }^{12}$ Therefore, we assumed that the receptor for $B$. pseudomallei on pharyngeal epithelial cells might be AGM1 and/or AGM2. Our data showed that although both AGM1 and AGM2 could inhibit the attachment of B. pseudomallei, AGM1 could inhibit attachment at a lower concentration than AGM2 and in a dose-dependent manner. The sequences of AGM1 and AGM2 are Gal( $\beta 1-3)$ GalNAc( $\beta 1-4) G a l(\beta 1-$ 4)Glc Cer and $\operatorname{GalNAc}(\beta 1-4) \operatorname{Gal}(\beta 1-4)$ Glc Cer, indicating that the constituents carbohydrates are glucose, galactose and $\mathrm{N}$-acetyl-galactosamine. To show the contribution of each carbohydrate, attachment inhibition was done. It was found that they could inhibit attachment only at a higher concentration $(1 \mathrm{mg} / \mathrm{ml})$, but not at a lower concentration (250 $\mu \mathrm{g} / \mathrm{ml})$. Fucose and mannose, two carbohydrates that are unrelated to AGM1 or AGM2, had no effect on attachment inhibition, even at a concentration of $1 \mathrm{mg} / \mathrm{ml}$. This indicates that the constituent carbohydrates of AGM1 and AGM2 cannot individually act as a receptor for B. pseudomallei. Four other clinical isolates of B. pseudomallei showed a significant decrease in attachment after treatment with AGM1. This shows the universality of AGM1 in inhibiting attachment to B. pseudomallei. From these data, we conclude that AGM1 and AGM2 are part of the receptor complex for B. pseudomallei on pharyngeal epithelial cells.

Attachment inhibition and TLC are two methods used to identify the receptors for bacteria on cells. Thin-layer chromatography requires many washing steps, which is thought to disturb the binding of bacteria and ganglioside ${ }^{13}$ because the binding of bacteria to lactosylceramide receptors is commonly weak. ${ }^{14}$ This low-affinity binding is suggested to be responsible for the inability of TLC to detect the receptors for Moraxella catarrhalis and Haemophilus influenzae. ${ }^{13,15}$ 
However, the attachment inhibition method identified the receptors for both $M$. catarrhalis and H. influenzae. ${ }^{16,17}$ Therefore, in this study the attachment inhibition method was used to detect the receptor for $B$. pseudomallei on pharyngeal epithelial cells.

The incidence of melioidosis is underestimated in many areas. It affects mainly malnourished and immunocompromised hosts. ${ }^{2}$ Studies in the United States and Singapore have shown that melioidosis can affect young military personnel without underlying illnesses. ${ }^{18,19}$ The nature of military training increases exposure of healthy, young individuals to the bacterium. Recently, the Center for Disease Control and Prevention (Atlanta, GA) designated B. pseudomalle $i$ as one of the pathogens most likely to be misused as a biologic weapon (Atlas RM, unpublished data). No vaccine is available for this infection, although a large number of people live in and travel to areas (Southeast Asia and northern Australia) where the bacteria is endemic. Part of the reason for not identifying a vaccine candidate is that the pathogenesis of this infection is unknown. The present study shows that attachment of B. pseudomallei is mediated by the AGM1-AGM2 receptor complex. Therefore, it may be possible to develop prevention methods for melioidosis based on the anti-attachment mechanism. Additional studies are needed to precisely identify the receptor sequence of $B$. pseudomallei.

Acknowledgments: Ahmad Hamid Gori was a participant of the Group Training Course in Research for Tropical Medicine, 1998, supported by the Japan International Cooperation Agency (JICA). We thank Sar Boran, Yoko Terai, and Hiroshi Watanabe for cooperation during this study.

Financial support: This project was supported in part by the Infection Control of Acute Respiratory Infections in the Developing Countries Grant from National Center for International Medical Cooperation, Ministry of Health and Welfare, Japanese Government.

Authors' addresses: Ahmad Hamid Gori, Ministry of Health, Medical District North N'djamena, PO Box 44, N'djamena, Chad. Kamruddin Ahmed, Glenda Martinez, Hironori Masaki, Kiwao Watanabe, and Tsuyoshi Nagatake, Department of Internal Medicine, Institute of Tropical Medicine, Nagasaki University, 1-12-4 Sakamotomachi, Nagasaki 852-8102, Japan.

Reprint requests: Kamruddin Ahmed, Department of Internal Medicine, Institute of Tropical Medicine, 1-12-4 Sakamoto-machi, Nagasaki 852-8102, Japan.

\section{REFERENCES}

1. White NJ, 1994. Melioidosis. Zentralbl Bakteriol 280: 439-443.

2. Leelarasamee A, Bovornkitti S, 1989. Melioidosis: review and update. Rev Infect Dis 11: 413-425.

3. Silberman MH, Gyssens IC, Endtz HP, Kuijper EJ, van der Meer JT, 1997. Two patient with recurrent melioidosis after prolonged antibiotic therapy. Scand J Infect Dis 29: 199-201.
4. Chaowagul W, 1996. Melioidosis; a treatment challenge. Scand J Infect Dis 101 (suppl): 14-16.

5. Rajchanuvong A, Chaowagul W, Suputtamongkol Y, Smith MD, Dance DA, White NJ, 1995. A prospective comparison of coamoxiclav and the combination of chloramphenicol, doxycycline, and co-trimoxazole for the oral maintenance treatment of melioidosis. Trans R Soc Trop Med Hyg 89: 546-549.

6. Thamprajamchit S, Chetchotisakd P, Thinkhamrop B, 1998. Cefoperazone/sulbactam + co-trimoxazole vs. ceftazidime + cotrimoxazole in the treatment of severe melioidosis: a randomized, double-blind, controlled study. J Med Assoc Thai 81: 265-271.

7. Chaowagul W, Suputtamongkul Y, Smith MD, White NJ, 1997. Oral fluoroquinolones for maintenance treatment of melioidosis. Trans R Soc Trop Med Hyg 91: 599-601.

8. Kanaphun P, Thirawattanasuk N, Suputtamongkol Y, Naigowit P, Dance DAB, Smith MD, White NJ, 1993. Serology and carriage of Pseudomonas pseudomallei: a prospective study in 1,000 hospitalized children in northeast Thailand. J Infect Dis 167: 230-233.

9. Huxley EJ, Viroslav J, Gray WR, Pierce AK, 1978. Pharyngeal aspiration in normal adults and patients with depressed consciousness. Am J Med 64: 564-568.

10. Ahmed K, Enciso HDR, Masaki H, Tao M, Omori A, Tharavichikul P, Nagatake T, 1999. Attachment of Burkholderia pseudomallei to pharyngeal epithelial cells: a highly pathogenic bacteria with low attachment ability. Am J Trop Med Hyg 60: 90-93.

11. Krivan HC, Ginsburg V, Roberts DD, 1988. Pseudomonas aeruginosa and Pseudomonas cepacia isolated from cystic fibrosis patients bind specifically to gangliotetraosylceramide (asialo GM1) and gangliotriaosylceramide (asialo GM2). Arch Biochem Biophys 260: 493-496.

12. Kanai K, Suzuki Y, Kondo K, Maejima Y, Miyamoto D, Suzuki T, Kurata T, 1997. Specific binding of Burkholderia pseudomallei cells and their cell-surface acid phosphatase to gangliotetraosylceramide (asialo GM1) and gangliotriaosylceramide (asialo GM2). Southeast Asian J Trop Med Public Health 28. 781-790.

13. van Alphen L, Geelen-van den Broek L, Blass L, van Ham M, Dankert J, 1991. Blocking of fimbriae-mediate adherence of Haemophilus influenzae by sialyl gangliosides. Infect Immun 59: 4473-4477.

14. Karlsson K-A, 1989. Animal glycosphingolipid as membrane attachment sites for bacteria. Annu Rev Biochem 58: 309-350.

15. Rikitomi N, Andersson B, Matsumoto K, Lindstedt R, Svanborg C, 1991. Mechanism of adherence of Moraxella (Branhamella) catarrhalis. Scand J Infect Dis 23: 559-567.

16. Ahmed K, Matsumoto K, Rikitomi N, Nagatake T, 1996. Attachment of Moraxella catarrhalis to pharyngeal epithelial cells is mediated by a glycosphingolipid receptor. FEMS Microbiol Lett 135: 305-309.

17. Kawakami K, Ahmed K, Utsunomiya Y, Rikitomi N, Hori A, Oishi K, Nagatake T, 1998. Attachment of nontypable Hemophilus influenzae to human pharyngeal epithelial cells is mediated by a ganglioside receptor. Microbiol Immunol 42: 697-702.

18. Howe C, Sampath A, Spotnitz M, 1971. The Pseudomallei group: A review. J Infect Dis 124: 598-606.

19. Lim MK, Tan EH, Soh CS, 1997. Burkholderia pseudomallei infection in the Singapore armed forces from 1987 to 1994an epidemiological review. Ann Acad Med Singapore 26: 1317. 